\title{
Foraging behavior of antarctic krill Euphausia superba on sea ice microalgae
}

\author{
James J. Stretch ${ }^{1, *}$, Peggy P. Hamner ${ }^{1}$, William M. Hamner ${ }^{1}$, William C. Michel ${ }^{1, * *}$, \\ Jared Cook $^{2, * * *}$, Cornelius W. Sullivan ${ }^{3}$ \\ ${ }^{1}$ Department of Biology, University of California, Los Angeles, California 90024, USA \\ ${ }^{2}$ Marine Science Institute, University of California, Santa Barbara, California 93106, USA \\ ${ }^{3}$ Department of Biological Sciences, University of Southern California, Los Angeles, California 90089-0371, USA
}

\begin{abstract}
The feeding behavior of antarctic krill Euphausia superba on ice algae was observed in situ and in the laboratory. Field observations by divers confirm that krill utilize natural sea ice microalgae for food. Laboratory investigations show that melting ice releases algae into the water column which induces area-intensive foraging behavior in krill. This behavior is characterized by high speed swimming and rapid turning, accompanied by rapid opening and closing of the thoracic appendages, also known as the feeding basket. Presentation of increased concentrations of ice algae to laboratory populations of krill significantly increased euphausiid responsiveness which led to location of and direct grazing upon the undersurfaces of ice containing microalgae. Foraging behavior of krill on ice algae appears to be affected by the spatial patchiness of the algae within the ice and on the rate of algal cell release from ice. We propose that sea ice algae is an abundant and predictable food resource for krill during austral winters, when phytoplankton food resources are depleted.
\end{abstract}

\section{INTRODUCTION}

Antarctic krill Euphausia superba Dana have been observed by many investigators in association with sea ice (Marr 1962, Meguro 1962, Hewes et al. 1983, Ainley \& Sullivan 1984, Boyd et al. 1984, Kottmeier \& Sullivan 1987). Epontic ice algae communities grow in and under sea ice (Meguro 1962, Bunt 1963, Bunt \& Lee 1970, Hoshiai 1977, Garrison et al. 1986) and quite probably are an important source of food for krill (Spiridonov et al. 1985). Pseudocalanus sp. aggregates in densities up to $10^{6} \mathrm{~m}^{-3}$ and exhibits maximum feeding rates when associated with arctic sea ice algal communities (Conover et al. 1986). However, until recently, there was no direct evidence that antarctic krill could exploit ice algae as a food resource. Hamner et al. (1983) observed krill feeding on concentrated ice algal assemblages and on phytoplankton cultures that had been frozen into ice blocks in the laboratory. That

\footnotetext{
Present addresses:

- Blue Water Consulting, 6382 Adobe Circle Rd, Irvine, California 92715, USA

- Department of Zoology and Physiology, Louisiana State University, Baton Rouge, Louisiana 70803, USA

-. PO Box 288, Glen Ellen, California 95442, USA
}

study remains the only investigation presenting evidence that krill may utilize ice algae as a source of food. Recently, divers noted the occurrence of foraging by krill under sea ice (Garrison et al. 1986), but they did not provide descriptions of the natural foraging behavior of krill on ice algae.

Ice algal communities may be an important nutrient resource for Euphausia superba and may help explain how krill survive over austral winters when stocks of phytoplankton are severly depleted (Ikeda \& Dixon 1982, Ettershank 1983, Boyd et al. 1984, Ikeda 1985). Ikeda \& Dixon (1982) have observed that krill shrink when starved and propose that body shrinkage, as a result of a food-depleted environment, may aid in the survival of krill during the antarctic winter. The relative importance of these proposed strategies as a means for surviving long periods of starvation has not been assessed for any natural populations. Holm-Hansen \& Huntley (1984) argue that the contribution of ice algal communities to the overall annual productivity in the Southern Ocean is low and probably is not a significant source of food for krill, and then state that ice algal communities 'may be important as a food source in localized areas and also to sustain overwintering populations of zooplankton'. The release of epontic algae to 
the water column underlying sea ice does produce locally high concentrations of microalgae (El Sayed 1971) over relatively broad geographic areas of the Southern Ocean (Smith \& Nelson 1986).

Ikeda (1985) has evaluated his earlier negative growth model (Ikeda \& Dixon 1982) and proposed that when food is limited, body shrinkage should prohibit krill from attaining body lengths of greater than $45 \mathrm{~mm}$. Since krill up to $60 \mathrm{~mm}$ in body length are regularly observed among natural populations of krill, Ikeda (1985) concluded that the feeding conditions of krill during winter may not be so severe as total starvation'. More simply stated, Ikeda (1985) rejects the dogma that food is not generally available for krill during antarctic winters.

Antarctic krill do utilize sea ice microalgae as a nutrient resource. The importance of this resource to their overall metabolic and reproductive energetic requirements may not be fully appreciated until the foraging behavior of krill on this particular resource is understood. Therefore, we present here a series of investigations examining the feeding behavior that Euphausia superba exhibits when foraging on sea ice microalgae under natural and laboratory conditions.

\section{METHODS}

Temporal activity. Stock populations of Euphausia superba were maintained for experimental purposes at Palmer Station, Anvers Island, Antarctica $\left(64^{\circ} 46^{\prime} \mathrm{S}\right.$, $64^{\circ} 04^{\prime} \mathrm{W}$ ), during the austral summer $1981-82$ and winter 1985. Krill were fed by placing frozen blocks of concentrated phytoplankton and ice algal assemblages into holding aquaria. We observed distinct foraging behaviors among krill associated with these frozen algal blocks and designed behavioral assays and experiments to characterize these behaviors.

In the first assay, frozen algal blocks were placed into a $2000 \mathrm{l}$ aquarium containing approximately 10000 individual Euphausia superba. The behavior of these krill was recorded visually for 2 treatment conditions. A $500 \mathrm{ml}$ block of uniformly colored ice $\left(-10^{\circ} \mathrm{C}\right)$, indicating an even distribution of algal cells within the ice, was placed at the surface. Chlorophyll a concentrations were unknown; however a random sampling of similarly prepared ice blocks contained 610 to $1085 \mu \mathrm{g} \mathrm{l^{-1 }}$ of chlorophyll a. Another block of filtered $(5 \mu \mathrm{m})$ and frozen seawater $\left(-10^{\circ} \mathrm{C}\right.$, control) was placed at the surface a distance of $15 \mathrm{~cm}$ from the treatment block. Observations were conducted for a period of $122 \mathrm{~min}$, recording the number of krill grazing on the undersurface of the ice during the first $10 \mathrm{~s}$ of every $2 \mathrm{~min}$ interval. After $60 \mathrm{~min}$ the ice block positions were reversed to control for possible position bias
Ice algae are not uniformly distributed throughout ice (Hoshiai 1977. Ackley et al. 1979, Clarke \& Ackley 1982, 1984, Gosselin et a1. 1986); therefore, the responses of Euphausia superba to a layer of algae embedded in ice were also observed. In this second assay, a solitary ice block $(500 \mathrm{ml})$, containing a visually evident algal cell layer and maintained at $-30^{\circ} \mathrm{C}$ prior to the trial, was placed into the aquarium and the number of krill grazing on ice during a $10 \mathrm{~s}$ period every $2 \mathrm{~min}$ was again recorded visually for a period of $316 \mathrm{~min}$.

Ice algae concentrations. We evaluated the responses of Euphausia superba to various frozen microalgal concentrations, including ice algal assemblages obtained from nature and 3 frozen Nitzschia sp. cultures, using a video recorder. Krill were randomly presented with 5 different ice algal block treatments on 3 consecutive days. Three of the block treatments were prepared from a concentrated Nitzschia sp. culture, originally isolated from a phytoplankton tow taken in Arthur Harbor, Anvers Island. These included frozen blocks $\left(-17^{\circ} \mathrm{C}, 32 \%\right.$ salinity $)$ of ten- $(1: 10)$ and hundred-fold $(1: 100)$ dilutions of the concentrated Nitzschia sp. culture (1:1). A fourth treatment block consisted of ice algae obtained from Arthur Harbor on 14 October 1985 (4\% salinity). This natural ice was thawed and refrozen into block shapes that were similar to the shape of the Nitzschia sp. culture blocks prepared above. Filtered seawater ice (1.4 $\mu \mathrm{m}$ mesh) served as the fifth treatment and experimental control (32\% salinity). All ice blocks were approximately 300 $\mathrm{ml}$ in volume. Five trial periods, lasting $44 \mathrm{~min}$ each, were consecutively run on each of the $3 \mathrm{~d}$, yielding 3 replicates for each treatment block.

This experiment was conducted on male Euphausia superba in a holding aquarium provided with raw (unfiltered) seawater from Arthur Harbor containing approximately $0.4 \pm 0.04 \mu \mathrm{m}$ chlorophyll a $\mathrm{l}^{-1}(n=3)$. Approximately $1000 \mathrm{krill}$ were maintained in this $450 \mathrm{l}$ aquarium. The experiment began with the introduction of an ice block to the surface of the aquarium where ambient water temperatures ranged from -0.4 to $-1.0^{\circ} \mathrm{C}$. The behavior of krill in a 31.5 l volume $(31.4 \times$ $22.9 \times 43.8 \mathrm{~cm})$ below the ice block was recorded on video tape. Behavior of krill in the remaining $418.5 \mathrm{l}$ was not quantified. Trial periods arbitrarily lasted 44 min after which the ice was removed. The next ice block treatment (randomly determined) was then placed on the aquarium water surface and the next trial begun. Video-recorded responses were later scored by an observer unfamiliar with the treatment presentation sequence.

In situ observations and ice algae assays. We used SCUBA to observe the behavior of field populations of Euphausia superba (Hamner 1975, 1982). Chlorophyll $a$ and phaeophytin concentrations were determined 
fluorometrically (Strickland \& Parsons 1968). Natural ice algal samples were preserved for floristic analyses in a solution of glutaraldehyde $(1 \%)$, formalin $(2 \%)$, and Lugol's iodine ( $1 \mathrm{drop} \mathrm{ml}^{-1}$ of sample). Individual microalgal species were filtered on Nuclepore filters (1 $\mu \mathrm{m}$ pore size) and enumerated by the technique described by Grossi \& Sullivan (1985) using a Zeiss research microscope with phase contrast optics and an epi-illuminator for fluorescence microscopy.

\section{RESULTS}

\section{Foraging behavior under ice containing microalgae}

When Euphausia superba forage near ice floes containing sea ice microbial communities they exhibit distinct behavioral patterns. The first foraging pattern occurs when the euphausiid is stimulated by algal cells, and/or extracellular materials released from lysed algal cells, that enter the water column from under-ice surfaces. Observations of the flow dynamics of melting blocks of frozen seawater-fluorescein solutions indicate that ice algae do not diffuse directly into the water column. Rather, they flow with high density brine along the undersurface of the ice to the lowest point on the under-ice surface where they then stream directly down into the water column. When E. superba come into contact with downwelling streams containing mi- croalgae, they begin turning, somersaulting, and rapidly swimming. These behaviors are also accompanied by rapid opening and closing of the feeding basket. The aggregates of these behaviors have been characterized as 'feeding frenzies' for krill foraging in patches of high food concentrations (Hamner 1984).

Frenzied feeding behavior is often followed by ice grazing behavior. Ice grazing is defined as the behavior that occurs when euphausiids orient to the undersurface of ice to rake algal cells off the ice with their thoracic endopodites (Hamner et al. 1983). We observed this behavior in the field while diving in the Plata Channel off the Gerlache Strait on 16 March 1984. A school of krill were swimming and feeding within $1 \mathrm{~m}$ of the surface. A small percentage of the school's members had left the school, ascended, and were feeding under and directly on the undersurfaces of the sea ice. This places the animal in a vertical to upside-down position while foraging. Juvenile Euphausia superba have also been observed to forage in a similar fashion by two of us (W.M.H. and P.P.H.) while diving in the Gerlache Strait during the austral summer of $1985-86$.

\section{Temporal activity}

Euphausia superba responded strongly to microalgae released from and embedded in sea ice. Fig. 1 depicts the frequency of individual E. superba grazing

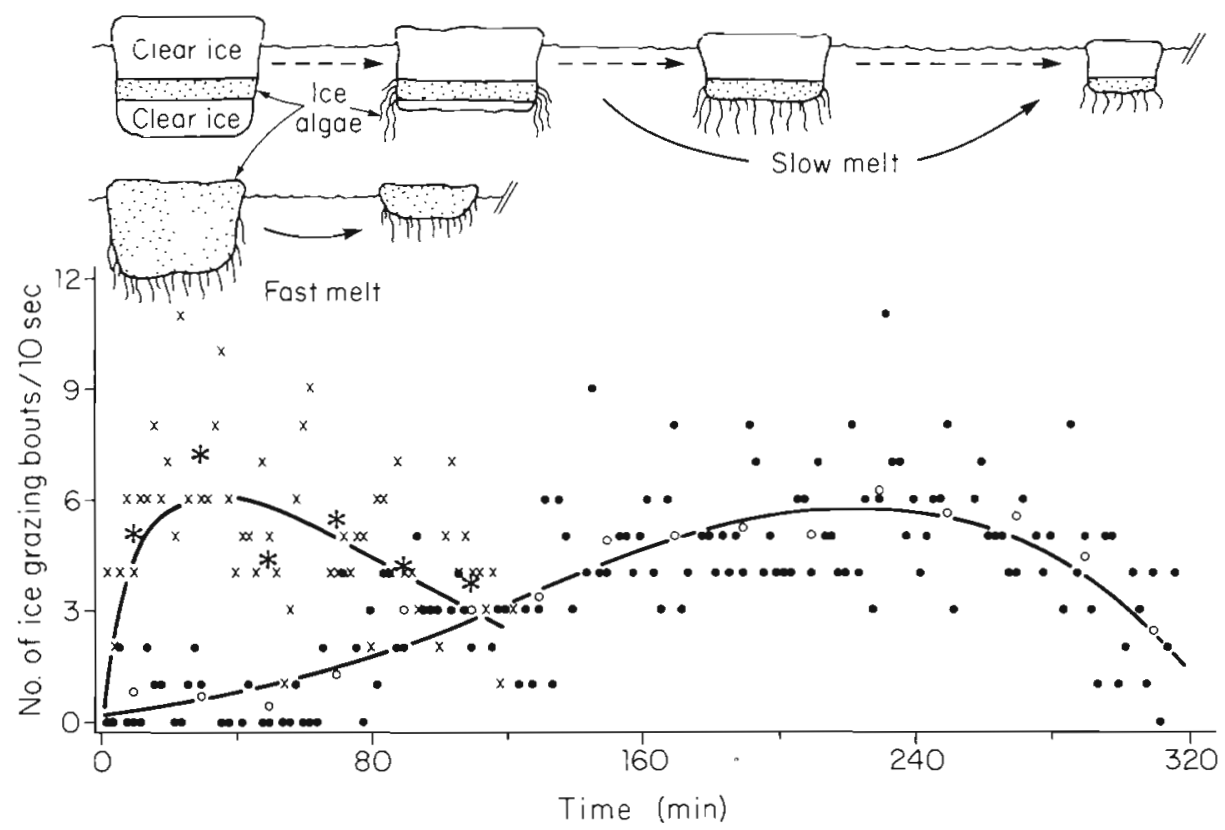

Fig. 1. Euphausia superba. Total number of krill grazing on ice for $10 \mathrm{~s}$ intervals every $2 \mathrm{~min}$. (x) Number of individuals that fed on a block of ice with a uniform distribution of concentrated, natural ice algae refrozen at $-10^{\circ} \mathrm{C}$, thereby resulting in a 'fast melt' when presented to krill; $(*)$ response means for each fast melt 20 min interval. ( $\bullet$ ) Numbers of individuals that fed on a clear iceice algal block refrozen at $-30^{\circ} \mathrm{C}$, thereby resulting in a 'slow melt' treatment; (c) response means for each slow melt 20 min interval. Curves were approximated from a cubic regression of points from each behavioral trial 
on frozen algal blocks over time. Ice with a uniform distribution of algae elicited a high incidence of ice grazing by E. superba within the first 20 min of the 122 min trial period. No responses to filtered seawater ice were observed during the trial even when the positions of the algal ice block and the seawater ice block (control) were reversed. The experimental ice algal block had almost entirely melted at 122 min into the trial. The number of ice-grazing incidents diminished gradually after the first 20 to 40 min. The mean duration ( \pm standard deviation) of individual ice-grazing bouts by $E$. superba for this experiment was $11.9 \pm 8.7 \mathrm{~s}$ ( $\mathrm{n}=$ 202).

Euphausia superba exposed to ice with an embedded band of algal cells responded in a similar fashion but over a different time scale (Fig. 1). This experimental ice block melted at a slower rate presumably because it had been maintained at $-30^{\circ} \mathrm{C}$ prior to the trial. The frequency of frenzied feeding was not quantified; however the number of ice-grazing bouts per $10 \mathrm{~s}$ increased as the ice algal layer was exposed. The frequency of such bouts attained levels similar to that observed in the treatment with algal cells uniformly distributed throughout ice (Fig. 1). The number of these responses diminished as the exposed ice algal layer melted. No algal cells, as discerned by green coloration of the ice, could be seen within the ice after $301 \mathrm{~min}$. Clearly, both the rate of melting of ice containing algal cells and the patchiness of those cells within the ice affect the foraging behavior of krill.

Ice algae concentrations. Krill also respond selectively to different concentrations of algae within the ice. Five frozen treatments, including 3 different concentrations of a Nitzschia sp. from laboratory culture, a sea ice algal treatment collected from Arthur Harbor, and filtered seawater controls, were prepared. The intensity of foraging responses by Euphausia superba to these treatments was strongly affected by the quantity (i.e. concentrations of chlorophyll a) of algal material in each ice treatment (Table 1). The null hypothesis $\left(H_{0}\right)$ that there is no difference in the mean number of frenzied feeding, ice grazing, and tailflipping responses by E. superba to ice blocks containing different concentrations of chlorophyll a was tested using a 1-way analysis of variance (Sokal \& Rohlf 1969). Assumptions of variance homogeneity for all behavioral response means were confirmed using the $F_{\text {max }}$-test ( $p=0.05$; Sokal \& Rohlf 1969). The mean numbers of individual feeding-frenzy responses between each of 5 ice treatment conditions (Table 1) was found to differ significantly $(p<0.0001)$. A posteriori application of the Student-Newman-Keuls (SNK) procedure, when the $H_{0}$ was rejected, showed that the number of frenzied feeding responses to Arthur Harbor sea ice, dilute Nitzschia, and control treatments were significantly lower than those for the 2 highest concentrations of Nitzschia ice $(p<0.05$; Table 1$)$.

The mean numbers of individual ice-grazing bouts and tailflips per trial (Table 1) were different between ice treatments $(p<0.0001$ and 0.005 , respectively; 1 way ANOVA). Concentratred Nitzschia sp. ice induced the highest incidences of ice grazing $(86.0 \pm 13.7$ responses per trial) and tailflipping $(46.7 \pm 14.6$ per trial) among krill tested (Table $1 ; p<0.05$, SNK). Krill

Table 1. Euphausia superba. Mean (standard deviation) number of individual behavioral responses of krill to frozen Nitzschia sp. cultures, sea ice obtained from Arthur Harbor, and frozen (1.4 $\mu \mathrm{m}$ filtered) seawater during 44 min trial periods. Mean (standard deviation) chlorophyll a concentrations, in $\mu \mathrm{g}^{-1}$, are given with each ice algal treatment. $n=3$ for all means. Within individual response categories, similar means (as determined by an a posteriori SNK procedure; $p>0.05$ ) are similarly underlined when the null hypothesis of mean equality was rejected with a 1-way ANOVA $(p<0.05)$

\begin{tabular}{|c|c|c|c|c|c|c|}
\hline Individual responses & $\begin{array}{c}\text { Nitzschia } \\
\text { culture ice } \\
657.61(4.32) \\
1.1\end{array}$ & $\begin{array}{c}\text { Nitzschia } \\
\text { culture ice } \\
65.44(3.81) \\
11.10^{\prime}\end{array}$ & $\begin{array}{l}\text { Ice treatment } \\
\text { Nitzschia } \\
\text { culture ice } \\
6.58(1.73) \\
11100^{\circ}\end{array}$ & $\begin{array}{c}\text { Arthur Harbor } \\
\text { sea ice } \\
91.95(6.40)\end{array}$ & $\begin{array}{c}\text { Control ice } \\
\text { (filtered } \\
\text { seawater) } \\
0.03(0.02)\end{array}$ & $\begin{array}{c}\text { ANOVA } \\
\text { (p) }\end{array}$ \\
\hline Feeding frenzies & $\begin{array}{r}108.7 \\
(3.8)\end{array}$ & $\begin{array}{c}29.3 \\
(12.7)\end{array}$ & $\begin{array}{c}9.3 \\
(6.5)\end{array}$ & $\begin{array}{c}8.7 \\
(3.5)\end{array}$ & $\begin{array}{c}5.0 \\
(2.6)\end{array}$ & $<0.0001$ \\
\hline Ice-grazing bouts & $\begin{array}{c}86.0 \\
(13.7)\end{array}$ & $\begin{array}{l}13.3 \\
(7.5)\end{array}$ & $\begin{array}{c}3.3 \\
(1.5)\end{array}$ & $\begin{array}{r}21.0^{\circ} \\
(10.1)\end{array}$ & $\begin{array}{c}2.3 \\
(1.5)\end{array}$ & $<0.0001$ \\
\hline Tailflips & $\begin{array}{c}46.7 \\
(14.6)\end{array}$ & $\begin{array}{l}14.7 \\
(1.5) \\
\end{array}$ & $\begin{array}{l}15.0 \\
(4.6) \\
\end{array}$ & $\begin{array}{l}10.3 \\
(6.7)\end{array}$ & $\begin{array}{l}12.7 \\
(7.1) \\
\end{array}$ & $<0.005$ \\
\hline Individuals in score area & $\begin{array}{l}336.0 \\
(17.4)\end{array}$ & $\begin{array}{l}258.7 \\
(74.5)\end{array}$ & $\begin{array}{l}241.3 \\
(50.3)\end{array}$ & $\begin{array}{l}215.3 \\
(20.5)\end{array}$ & $\begin{array}{l}252.7 \\
(44.3)\end{array}$ & $>0.05$ \\
\hline
\end{tabular}


grazed Arthur Harbor sea ice treatments more frequently than control ice treatments as determined by planned paired comparisons ( $p<0.05$; Student's $t$-test). A posteriori multiple comparisons of response frequencies to concentrated Nitzschia ice and all other treatments show that Euphausia superba exhibited fewer bouts of ice grazing and tailflipping when exposed to less concentrated ice algal and control treatments $(p<0.05 ;$ SNK). Although control and Arthur Harbor sea ice algal treatment salinities differed by nearly an order of magnitude, these treatment differences did not produce significant differential responses among either frenzied feeding or tailflipping behaviors (Table 1).

The total number of krill that entered the scoring area during each trial (i.e. the instantaneous number at each min, summed over the $44 \mathrm{~min}$ trial period) did not differ between ice treatments $(p>0.05$; 1 -way ANOVA). Therefore, the changes in numbers of krill responding to ice algal blocks with different concentrations of algae was not due to a differential in the number of krill that passed through the score area during the different trials.

Examination of the frequency of behaviors through time showed that Euphausia superba responded more often during the first $10 \mathrm{~min}$ of the trial period, with few exceptions (Fig. 2). Peak response frequencies for all behaviors were reached within this first 10 min period for the 2 most concentrated Nitzschia ice treatments (Fig. 2). Relatively high behavioral frequencies were maintained over time only in response to concentrated Nitzschia treatments.

\section{Incidence of natural ice algal communities}

Our observations of naturally occurring sea ice algae were limited to periods when brash ice was blown by prevailing weather into Arthur Harbor from the Bellingshausen Sea. Ice discolored by the presence of microalgae was not observed from May to August 1985. We observed brown sea ice 7 times during September and twice during October 1985. Highly discolored sea ice samples were collected at random for pigment analyses on 21 September, 14 October and 31 October 1985. Mean chlorophyll a concentrations ( \pm standard deviation, $n=3$ for all samples on each date) ranged from $92.0 \pm 6.4$ to $218.6 \pm 5.6 \mu \mathrm{g} \mathrm{l}^{-1}$. Mean phaeophytin concentrations, available from October samples only, ranged from $30.3 \pm 2.4$ to $74.1 \pm 3.8 \mu \mathrm{g} \mathrm{l^{-1 }}$. Mean salinity for October brash ice samples was $4 \%$. Algal species composition of October brash ice is listed in Table 2.

\section{DISCUSSION}

These field and laboratory observations describe the foraging behavior of Euphausia superba on sea ice microalgae. Our observations show that krill orient to
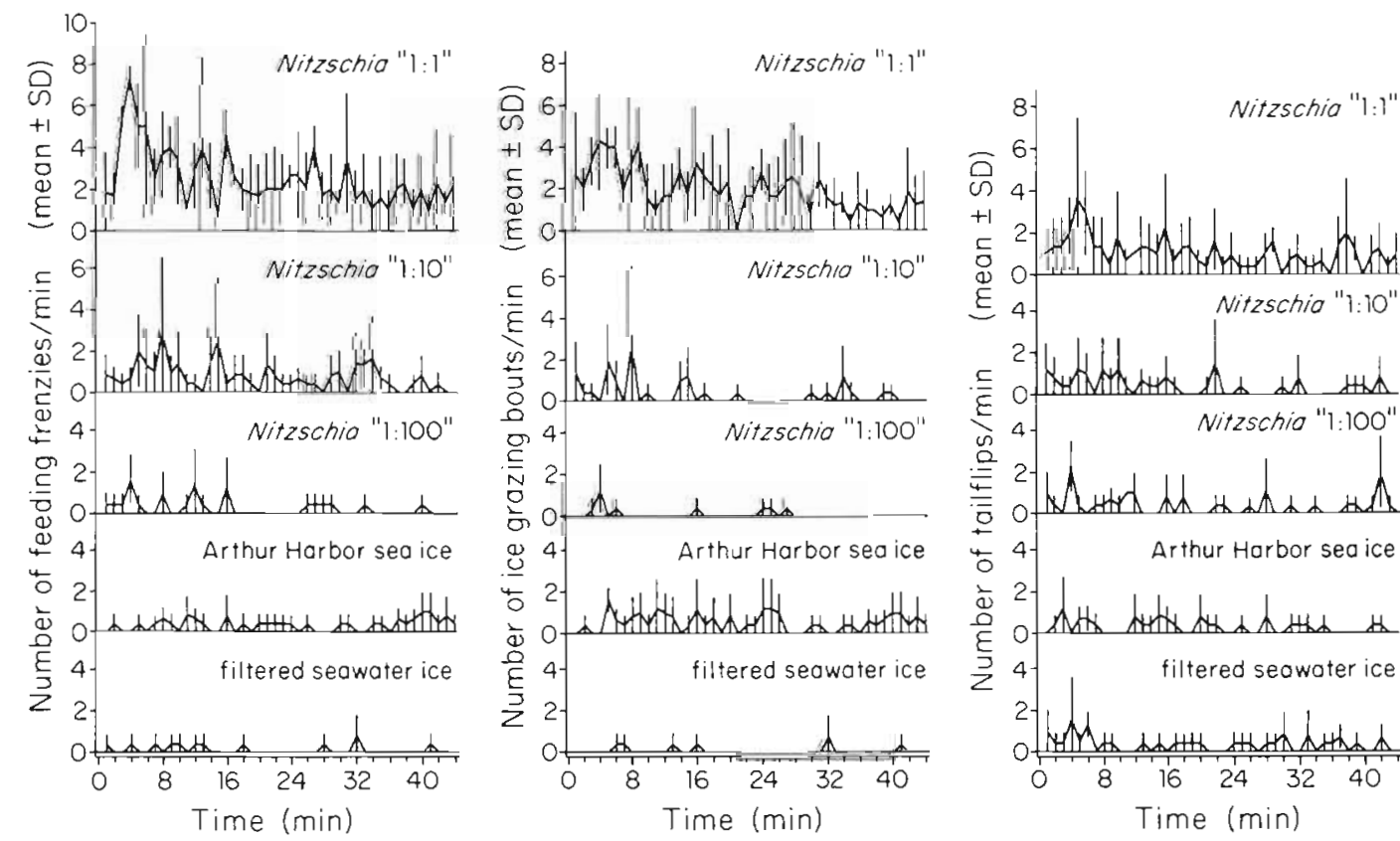

Fig. 2. Euphausia superba. Mean number of behavioral responses per min by krill exposed to 5 ice algal treatments over a 44 min trial period ( $n=3$ for all means; error bars $= \pm 1$ standard deviation). Temporal response patterns of individual krill to the 5 treatments includes (left) feeding frenzies, (center) ice grazing bouts, and (right) tailflips 
Table 2. Floristic composition and percent abundance of algal species in brash ice samples collected from Arthur Harbor, Anvers Island, during October 1985

\begin{tabular}{|c|c|c|c|}
\hline \multicolumn{2}{|c|}{14 October 1985} & \multicolumn{2}{|c|}{31 October 1985} \\
\hline Species & $\begin{array}{c}\text { Abundance } \\
(\%)\end{array}$ & Species & $\begin{array}{c}\text { Abundance } \\
(\%)\end{array}$ \\
\hline Thalassiosira antarctica & 25.8 & Porosira glacialis & 40.5 \\
\hline Porosira glacialis & 25.2 & Thalassiosira antarctica & 21.6 \\
\hline Coscinodiscus furcatus & 12.4 & Porosira pseudodenticulata & 13.0 \\
\hline Nitzschia cylindrus & 9.5 & Cocconeis fasciolata & 9.6 \\
\hline Nitzschia lineata & 8.6 & Charcotia actinochilus & 8.1 \\
\hline Thalassiosira ritscherï & 4.9 & Nitzschia lecointei & 3.0 \\
\hline Nitzschia kerguelensis & 3.9 & Nitzschia cylindrus & 1.1 \\
\hline Navicula glaciei & 3.2 & Rhizosolenia truncata & 0.6 \\
\hline Coscinodiscus pyrenoidophorus & 2.8 & Navicula directa & 0.5 \\
\hline Rhizosolenia alata & 1.8 & Pinnularia quadratarea & 0.2 \\
\hline Pinnularia quadratarea & 1.6 & Nitzschia kerguelensis & 0.2 \\
\hline Corethron criophilum & 0.1 & Nitzschia closterium & 0.2 \\
\hline Tropidoneis vanheurckii & 0.1 & Nitzschia curta & 0.2 \\
\hline Charcotia actinochilus & 0.1 & Corethron criophilum & 0.1 \\
\hline Phaeocystis sp. & $<0.1$ & Eucampia antarctica & 0.1 \\
\hline \multirow[t]{2}{*}{ Melosira subhyalina } & $<0.1$ & Coscinodiscus asteromphalus & 0.1 \\
\hline & & Phaeocystis sp. & 0.1 \\
\hline
\end{tabular}

and locate particular areas of high food concentration in the form of epontic microalgae. When stimulated by algae released from ice, E. superba exhibits a frenzied, area-intensive search behavior, characterized by increased turning and swimming rates. Although these rates were not quantitatively measured, they were qualitatively assessed by experienced behaviorists. Technical equipment necessary to quantify motion in 3 dimensions was not available. Regardless of these limitations, we found that when ice algal cells were experimentally presented in greater concentrations or when algal cells were released from ice at faster rates due to differential melting, a higher proportion of krill successfully located and grazed upon these microalgal cells at the ice/water interface. Such intensified foraging was accompanied by increased solitary tailflipping behavior, presumably resulting from hyperstimulation of krill by sharp algal concentration gradients. Tailflipping rarely occurred as a result of interference interactions among greater numbers of krill attempting to feed in localized areas.

The floristic composition of brash ice samples from October (Table 2) was similar to the sea ice flora reported for the region by Krebs (1983). However, the sea ice algal species compositions reported here and by Krebs (1983) were distinctly different from those reported for antarctic fast ice (Bunt 1963, McConville \& Wetherbee 1983, Palmisano \& Sullivan 1983, Hoshiai 1977) and Weddell Sea pack ice (Ackley et al. 1979, Garrison \& Buck 1985). Samples from the vicinity of Palmer Station were dominated by centric rather than pennate species of diatoms.
Krill are known to be sensitive to water-borne chemical stimuli (Hamner et al, 1983). Our in situ observations have shown that non-feeding krill are usually oriented and swimming in a particular direction within schools. When stimulated by a concentrated food resource this collective behavior is abandoned and each individual exhibits increases in swimming and turning behavior associated with searching. Such behavior appears to increase the time spent foraging in particular patches while also enhancing their chances of encountering downwelled epontic algae released from the sea ice above. Hamner (1984) concluded that the frenzied feeding behavior of krill foraging in concentrated phytoplankton patches maximizes their search and capture potential. If this area-intensive foraging ultimately leads to location of and grazing upon highly concentrated food resources (Hamner et al. 1983), it may be reasonable to conclude that the rapid turning, somersaulting, and swimming behavior associated with frenzied feeding is actually a complex and adaptive chemotactic/mechanoreceptive response to the presence of food gradients. Three-dimensional motion analyses are needed to evaluate this speculation.

Area-intensive foraging by Euphausia superba feeding on ice algae may be adaptive for 2 reasons. First, krill foods, like most aquatic resources, are patchily distributed in the Southern Ocean. The ability to feed episodically on patchily distributed resources may be more efficient than continuous feeding across wide food gradients (Hamner et al. 1983). Second, ice algal communities may be the only source of nutrition, 
excluding carnivory, detrivory, and cannabalism, for krill during the winter. We do not recognize that $E$. superba utilizes benthic sediments as a nutritional resource (Mauchline \& Fisher 1969) since no direct evidence has been presented to date to support this contention.

The ability of Euphausia superba to survive during winter periods of low production may be due to a combination of energetic adaptations. Ikeda \& Dixon (1982) proposed that body shrinkage conserves energy and thereby helps to sustain over-wintering krill populations. Others cite the possibility, but doubt the importance, of ice algae as a general nutrient resource for antarctic krill (Holm-Hansen \& Huntley 1984, McConville et al. 1986). We have observed, in the laboratory and field, that krill exhibit foraging behaviors which allow them to eat phytoplankton, ice algae, other zooplankton, cast euphausiid molts, and members of their own species in what appears to be a highly opportunistic manner. Whatever the source of food during the austral winter, it is clear that krill do not exclusively depend on filtration of food from a presumably dilute medium to survive through antarctic winters.

Limited and low light levels during antarctic winters leads to the depletion of phytoplankton stocks which have been thought to provide the primary source of food for Euphausia superba (Hamner et al. 1983, HolmHansen \& Huntley 1984, Ross \& Quetin 1986). The problem of locating food during the winter may be further exacerbated by the light-dampening effects of snow cover on fast ice and sea ice sheets (Sullivan et al. 1985, Gosselin et al. 1986) which may extend hundreds of kilometers from the Antarctic continent. Productivity levels in the entire euphotic water column under sea ice are known to be low (El Sayed 1971, Holm-Hansen \& Huntley 1984, Ainley et al. 1986, Garrison et al. 1986, Smith \& Nelson 1986) and the annual production of ice algal communities has been estimated to represent only 4 to $9 \%$ of the annual production of antarctic open waters (Holm-Hansen et al. 1977, Holm-Hansen \& Huntley 1984). However, ice algal production is not distributed through a broad euphotic water column as in antarctic open waters. Rather, ice algal production is locally restricted to a narrow zone that includes the ice and the immediately underlying waters. Smith \& Nelson (1986) estimate that ice-edge-associated algae 'may produce an amount up to two times the total production over the rest of the growing season' for the entire Southern Ocean. El Sayed (1971) reported that chlorophyll a concentrations diminished from highs of $190 \mathrm{\mu g} \mathrm{l}^{-1}$ at the sea ice/water column interface to less than $2.8 \mu \mathrm{g} \mathrm{l}^{-1}$ at $1 \mathrm{~m}$ below this interface in the Weddell Sea. Our results show that ice algae concentrations of $65 \mu \mathrm{g}$ chlorophyll $\mathrm{al}^{-1}$ and above are suffi- cient to induce specialized foraging behavior in $E$. superba. Clearly, krill are sensitive to lower concentrations since ice algae are diluted as they enter the water column. Although absolute production rates under ice may be low, local surface levels of algal biomass within and directly under sea ice are relatively high and may, therefore, provide a rich source of food for antarctic epipelagic zooplankton (Kottmeier \& Sullivan 1987).

Ice algal communities may also be important to mature krill prior to and during the reproductive season. Ross \& Quetin (1986) estimate that average algal concentrations of 1 to $5 \mu \mathrm{g}$ chlorophyll a $\mathrm{l}^{-1}$ are necessary to maintain krill metabolic requirements and permit allocation of energy resources for the development of reproductive tissues. Such high chlorophyll a concentrations rarely exist in oceanic waters (HolmHansen \& Huntley 1984, Ross \& Quetin 1986). However, phytoplankton concentrations in the vicinity of the ice edge zones regularly exceed this range (El Sayed 1971, Smith \& Nelson 1986). Ice algal concentrations also exceed this range, often by orders of magnitude (Clarke \& Ackley 1984, Garrison et al. 1986). Surface algal blooms in the Southern Ocean seeded by the release of algal communities from ice (Smith \& Nelson 1986), may provide predictable and concentrated sources of food necessary for the gonad development and reproductive success of krill (Ross \& Quetin 1986). Kottmeier \& Sullivan (1987) have measured substantial levels of ice algal production during the austral winter (August 1985) near Dalmer Station. Combination of these measurements with in situ observations of juvenile krill aggregating near and foraging on visibly concentrated patches of ice algae, also during the winter (Kottmeier \& Sullivan 1987, Richard Moe pers. comm.), confirms that sea ice microbial communities are utilized by epipelagic populations of krill, regardless of their developmental stage, as year-round sources of nutrition.

Before we can thoroughly evaluate the importance of ice algal communities in contributing to the reproductive biology and persistence of Euphausia superba throughout the winter, more work is needed in the following areas: (1) detailed studies of the temporal and geographic distributions of antarctic ice algal communities; (2) understanding the mechanics of temporal and spatial release of algal cells to the water column from melting sea ice; (3) estimations of temporal and spatial distributions of krill; (4) estimations of the frequency with which krill naturally exploit ice algal communities; (5) further characterizations of the mechanics of area-intensive foraging and its quantitative efficiency; and (6) the effectiveness of grazing on ice algal surfaces and its contribution to euphausiid metabolic requirements. Such studies may also help to determine 
how the foraging behavior of krill affects the biology of ice algal communities (Garrison et al. 1986) as well as to describe the intraspecific interactions that take place when 3-dimensional schools of krill begin to feed on the 2-dimensional surfaces of ice containing sea ice microalgae.

Acknowledgements. We thank the captains and crews of the RV 'Hero' and RV 'Polar Duke' for their support in conducting field observations and collecting krill for laboratory experiments. We also thank N. Holland, R. Moe, R. Ross, and E. Scully for discussions on krill behavior and ice algal communities. The logistic support of ITT-Antarctic Services, Inc., and their winter-over $1985 \mathrm{crew}$, is appreciated. We also thank M. Haddon for assistance with computer graphics. The computer and manuscript preparational support provided to JJS by the Smithsonian Environmental Research Center, Edgewater, Maryland, is gratefully acknowledged. We also thank 4 anonymous reviewers for their comments on the manuscript. This research was supported by grants from the National Science Foundation, Division of Polar Programs, to W. M. Hamner (DPP83-02852 and DPP85-40817), L. Quetin and R. Ross (DPP82-18356), and C. W. Sullivan (DPP8444783).

\section{LITERATURE CITED}

Ackley, S. F., Buck, K. R, Taguchi, S. (1979). Standing crop of algae in the sea ice of the Weddell Sea region. Deep Sea Res. 26A: 269-281

Ainley, D. G., Fraser, W. R., Sullivan, C. W., Torres, J. J. Hopkins, T. L., Smith, W. O. (1986). Antarctic mesopelagic micronekton: evidence from seabirds that pack ice affects community structure. Science 232: 84,7-849

Ainley, D. G., Sullivan, C. W (1984). AMERIEZ 1983: a summary of activities on board RV Melville \& USCGC Westwind. Antarct. J. U. S. 19: 100-103

Boyd, C. M., Heyraud, M., Boyd, C. N. (1984). Feeding of the antarctic krill Euphausia superba. J. Crust. Biol. 4 (Spec. No. 1): 123-141

Bunt, J. S. (1963). Diatoms of antarctic sea ice as agents of primary production. Nature, Lond. 199: 1255-1257

Bunt, J. S., Lee, C. C. (1970). Seasonal primary production in antarctic sea ice at McMurdo Sound in 1967. J. mar. Res. 28: $304-320$

Clarke, D. B., Ackley, S. F. (1982). Physical, chemical, and biological properties of winter sea ice in the Weddell Sea. Antarct. J. U. S. 17: 107-109

Clarke, D. B., Ackley, S. F. (1984). Sea ice structure and biological activity in the antarctic marginal ice zone. J. geophys. Res. 89: 2087-2095

Conover, R. J., Herman, A. W., Prinsenberg, S. J., Harris, L. R. (1986). Distribution of and feeding by the copepod Pseudocalanus under fast ice during the arctic spring. Science 232: 1245-1247

El-Sayed, S. Z. (1971). Observations on phytoplankton bloom in the Weddell Sea. In: Schmitt, W. L., Llano, G. A. (eds.) Biology of the antarctic seas III. Antarct. Res. Ser. 17 301-312

Ettershank, G. (1983). Age structure and cyclical annual size change in the antarctic krill, Euphausia superba Dana. Polar Biol. 2: 189-193

Garrison, D. L., Buck, K. R. (1985). Sea-ice algal communities in the Weddell Sea: species composition in Ice and plank- tonic assemblages. In: Gray, J. S., Christiansen, M. E. (eds.) Marine biology of polar regions and effects of stress on marine organisms. John Wiley \& Sons, New York, p. $103-121$

Garrison, D. L., Sullivan. C. W., AckJey, S. F. (1986). Sea ice microbial communities in Antarctica. Bioscience 36 : 243-250

Gosselin, M., Legendre, L., Therriault, J.-C., Demers, S., Rochet, M. (1986). Physical control of the horizontal patchiness of sea-ice microalgae. Mar. Ecol. Prog. Ser. 29: 289-298

Grossi, S. McGrath, Sullivan, C. W. (1985). Sea ice microbial communities. $V$. The vertical zonation of diatoms in an antarctic fast ice community. J. Phycol. 21: 401-409

Hamner, W. M. (1975). Underwater observations of bluewater plankton: logistics, techniques, and safety procedures for divers at sea. Limnol. Oceanogr. 20: 1045-1051

Hamner, W. M. (1982). Procedures for in situ observations of krill in the Southern Ocean. Antarct. J. U. S. 17: 165

Hamner, W. M. (1984). Aspects of schooling in Euphausia superba. J. Crust. Biol. 4 (Spec. No. 1): 67-74

Hamner, W. M., Hamner, P. P., Strand, S. W., Gilmer, R. W. (1983). Behavior of antarctic krill, Euphausia superba: Chemoreception, feeding, schooling, and molting. Science 220: $433-435$

Hewes, C. D., Holm-Hansen, O., Sakshaug, E. (1983). Nanoplankton and microplankton studies during the circumnavigation cruise. Antarct. J. U.S. 18: 169-171

Holm-Hansen, O., El Sayed, S. Z., Franceschini, G. A., Cuhel, R. L. (1977). Primary production and the factors controlling phytoplankton growth in the southern ocean. In: Llano, G. A. (ed.) Adaptations within antarctic ecosystems. Proc. 3rd SCAR Symp. Antarct. Biol., Gulf Publ. Co., Houston, Texas, p. $11-50$

Holm-Hansen, O., Huntley, M. (1984). Feeding requirements of krill in relation to food sources. J. Crust. Biol. 4 (Spec. No. 1): $156-173$

Hoshiai, T (1977). Seasonal change of ice communities in the sea ice near Syowa Station, Antarctica. In: Dunbar, M. J (ed.) Polar oceans. Arctic Inst. North America, Calgary, Canada, p. 307-317

Ikeda, T., Dixon, P. (1982). Body shrinkage as a possible overwintering mechanism of the antarctic krill, Euphausia superba Dana. J. exp. mar. Biol. Ecol. 62: 143-151

Ikeda, T. (1985). Life history of antarctic krill Euphausia superba: a new look from an experimental approach. Bull. mar Sci. 37: 599-608

Kottmeier, S. T., Sullivan, C. W. (1987). Late winter primary and bacterial production in sea ice and seawater west of the Antarctic Peninsula. Mar. Ecol. Prog. Ser. 36: 287-298

Krebs, W. N. (1983). Ecology of neritic marine diatoms, Arthur Harbor, Antarctica. Micropaleontology 29: 267-297

Marr, J. W. S. (1962). The natural history of the antarctic krill (Euphausia superba Dana). Discovery Rep. 32: 33-464

Mauchline, J., Fisher, L. R. (1969). The biology of euphausiids. Adv. mar. Biol. 7: 1-454

McConville, M. J., Wetherbee, R. (1983). The bottom ice microalgal community from the annual ice in the inshore waters of East Antarctica. J. Phycol. 19: 431-439

McConville, M. J., Ikeda, T., Bacic, A., Clarke, A. (1986). Digestive carbohydrases from the hepatopancreas of two antarctic euphasuid species (Euphausia superba and $E$. crystallorophias). Mar Biol. 90: 371-378

Meguro, H. (1962). Plankton ice in the Antarctic Ocean Antarct. Rec. 14: 1192-1199

Palmisano, A. C., Sullivan, C. W. (1983). Sea ice microbial communities (SIMCO) I. Distribution, abundance, and 
primary production of ice microalgae in McMurdo Sound, Antarctica in 1980. Polar Biol. 2: 171-177

Ross, R. M., Quetin, L. B. (1986). How productive are antarctic krill? Bioscience 36: 264-269

Smith, W. O., Jr, Nelson, D. M. (1986). Importance of ice edge phytoplankton production in the Southern Ocean. Bioscience 36: 251-257

Sokal, R. R., Rohlf, F. J. (1969). Biometry. Freeman \& Co., San Francisco

Spiridonov, V. A., Gruzov, E. N., Puskin, A. F. (1985). Investigations of schools of antarctic Euphausia superba (Crus- tacea, Euphausiacea) under the ice. Zool. Zh. 64: $1655-1660$

Strickland, J. D. H., Parsons, T R. (1968). A practical handbook of sea water analysis. Bull. Fish. Res. Bd Can. 167

Sullivan, C. W., Palmisano, A. C., Kottmeier, S., Grossi, S McGrath, Moe, R. (1985). The influence of light on growth and development of the sea-ice microbial community of McMurdo Sound. In: Siegfried, W R., Condy, P. R., Laws, R. M. (eds.) Antarctic nutrient cycles and food webs. Springer-Verlag, Heidelberg, p. 78-83

This article was presented by Dr R. J. Conover; it was accepted for printing on February 18, 1988 